IZA DP No. 9152

A Tax Benefit Model for Policy Evaluation in Luxembourg: LuxTaxBen

Nizamul Islam

Lennart Flood

June 2015 


\title{
A Tax Benefit Model for Policy Evaluation in Luxembourg: LuxTaxBen
}

\author{
Nizamul Islam \\ CEPS/INSTEAD \\ Lennart Flood \\ University of Gothenburg \\ and IZA
}

\section{Discussion Paper No. 9152 \\ June 2015}

IZA
P.O. Box 7240
53072 Bonn
Germany

Phone: +49-228-3894-0

Fax: +49-228-3894-180

E-mail: iza@iza.org

\begin{abstract}
Any opinions expressed here are those of the author(s) and not those of IZA. Research published in this series may include views on policy, but the institute itself takes no institutional policy positions. The IZA research network is committed to the IZA Guiding Principles of Research Integrity.

The Institute for the Study of Labor (IZA) in Bonn is a local and virtual international research center and a place of communication between science, politics and business. IZA is an independent nonprofit organization supported by Deutsche Post Foundation. The center is associated with the University of Bonn and offers a stimulating research environment through its international network, workshops and conferences, data service, project support, research visits and doctoral program. IZA engages in (i) original and internationally competitive research in all fields of labor economics, (ii) development of policy concepts, and (iii) dissemination of research results and concepts to the interested public.
\end{abstract}

IZA Discussion Papers often represent preliminary work and are circulated to encourage discussion. Citation of such a paper should account for its provisional character. A revised version may be available directly from the author. 


\begin{abstract}

\section{A Tax Benefit Model for Policy Evaluation in Luxembourg: LuxTaxBen}

We develop a behavioural micro simulation model (LuxTaxBen) that contains very precise information on income tax rules, as well as eligibility-rules for a number of welfare programs, such as social assistance, housing allowance etc. The model has been built specifically for analysing the Luxembourgish tax-transfer system whereby one can generate disposable income for various combinations of hours of work and welfare. It can be used for calculating accurate (net) household incomes conditional on labour supply while income tax rules and the various welfare benefit-levels are complicated functions of earned and unearned income. The LuxTaxBen is capable to handle almost all parts of the Luxembourg tax and transfer systems. Such a model has a great potential to be used for evaluating the effects of taxbenefit policy reforms and other changes on poverty, inequality, incentives and the governmental budget. It provides the users the opportunity to simulate the new rules in the Luxembourg tax-transfer system. The model consists of a number of modules such as module for child benefit, housing allowance, fees for child care. It is constructed in an integrated way so all the modules can be used together. This means that it is possible to analyses the interaction between the different transfer systems.
\end{abstract}

JEL Classification: $\quad \mathrm{C} 8, \mathrm{D} 31, \mathrm{H} 24$

Keywords: micro simulation, distributional and behavioural effect, welfare

Corresponding author:

Lennart Flood

Department of Economics

School of Business, Economics and Law

University of Gothenburg

P.O. Box 600

SE 40530 Göteborg

Sweden

E-mail: Lennart.Flood@economics.gu.se 


\section{Introduction}

Policy evaluation has become an integrated part of the design of tax and benefit systems. In many countries the core part of this evaluation consists of a tax-transfer program that based on representative data for the population calculates the household net income. This technique is usually referred to as micro simulation and has become popular for their ability to provide a priori assessment of different policy designs (Amedeo Spadaro 2007). It is used in economic policy analysis in order to assess the distributional consequences of a tax or benefit changes among heterogeneous groups of families and to estimate the likely cost to the government of a proposed or hypothetical policy reform (Creedy and Duncan 2002). It used to simulate individual or household behavior due to change of tax-benefit system or other types of economic and financial activities.

There are several micro simulation models for taxation, pensions, and other types of economic and financial activity. They are based on a specific period in time and are typically implemented by the government agencies or researcher or academics. Examples of static model include TAXBEN from the IFS in London (Brewer et al., 2007), SWEtaxben (Ericson et al., 2009) for Sweden, IZAYMOD (Peichl et al., 2010) for Germany. The OECD Tax-Benefit model is another excellent instrument to program the tax benefit model for 38 countries (32 OECD countries and from 2005 Cyprus1, Latvia, Lithuania, Malta and from 2008 Bulgaria and Romania) for various family type. Another well-known micro simulation model for the European Union (EU) is EUROMOD. It enables to calculate and compare the effects of taxes and benefits on household incomes and work incentives for the population of each country and for the EU as a whole (Sutherland, 2007). Examples of dynamic micro-simulation, another stream of micro-simulation, include Pensim2 (a dynamic micro-simulation pension model) which dynamically simulates pension income for the next 50 years in the UK. LIAM (O’Donoghue et al., 2009), SESIM

(Flood, 2008; Klevmarken, 2010) and Belgium MIDAS (Dekkers et al., 2010; Dekkers and Belloni, 2009). North American dynamic micro-simulation CORSIM, DYNACAN (Canada) and POLISIM (United States). 
However the most common micro simulation models are static and are classified into two part: with and without behavioral model. Models without behavioural effects are simply tax and benefit calculators that calculate disposable income for each household before and after a policy change. It offers the "morning after" effects of specified changes in Tax-Benefits policy. These models can have a great value for many reforms and especially those that implies minor adjustments where the assumption of no behavioural change can be realistic. However for large reforms that has large effects on economic incentives, the assumption that the households do not adapt to these changes is not so realistic. Thus it is essential to consider a model that allows for behavioural changes.

A micro simulation model for social Budget "SOBULUX" has been developed by Ministry of Social Security (IGSS) aiming to analyze the long term pension budget in Luxembourg. LIAM2 (Gaëtan et al., 2014 ) is another micro simulation model that have been developed and verified first time at the Federal Planning Bureau (FPB), Belgium and later on verified by the Luxembourg Team (LISER and IGSS). LIAM2 is a partial dynamic micro simulation model can be useful to analyze pensions and social transfers in the longer period allowing Luxembourg and other countries. Berger, Islam and Liegeois (2011) analyses the effect of behavioral responses to the significant changes in the tax-benefit system during 2001-2002 in Luxembourg for single women and women in couple. Disposable income were calculated using the micro simulation model EUROMOD.

In the discrete choice labor supply literature it is often argued that if restriction is not applied a priory in the optimization program, the monotonicity condition is not fully satisfied ex post (Liegeois and Islam, 2012). Liegeois and Islam provide an alternative solution how to simply complete the standard maximum likelihood program in order to derive an optimum that may lead to positive marginal utilities. To evaluate the budget set at different levels for the hours worked, the EUROMOD tax-benefit static micro simulation model was used in this paper.

To the best of our knowledge so far no behavioural micro simulation model has been developed exclusively for Luxembourg. Therefore we develop a micro simulation model LuxTaxBen (Luxembourg Tax Benefit micro simulation model) where a sophisticated labour supply model 
has been integrated. The objective of this document is to give a description of LuxTaxBen. This model has a great potential to be used for evaluating the effects of tax-benefit policy reforms and other changes on poverty, inequality, incentives and the governmental budget. It contains very precise information on income tax rules, as well as eligibility-rules for a number of welfare programs, such as social assistance, housing allowance etc. It has been built specifically for analysing the Luxembourgish tax-transfer system whereby one can generate disposable income for various combinations of hours of work and welfare. It can be used for calculating accurate (disposable) household incomes, conditional on labour supply while income tax rules and the various welfare benefit-levels are complicated functions of earned and unearned income. It is constructed in an integrated way so all the tax and transfer modules can be used together. This means that it is possible to analyses the interaction between the different transfer systems. One objective of LuxTaxBen is to give the users the opportunity to analyze the effects of planned changes (new rules) in Luxembourg tax-benefit system. This model can be used by individual researchers as well as governmental and non-governmental offices. The current version of LuxTaxBen has been written in SAS-language.

The next section (section 2) describes a brief over view of LuxTaxBen. Section 3 describes the facilities of LuxTaxBen. Section 4 describes the robustness check by comparing various simulated/non simulated income components of EU-SILC, EUROMOD, and LuxTaxBen. Section 5 concludes the model after a short discussion.

\section{An over view of LuxTaxBen}

The LuxTaxBen is a static as well as behavioural micro simulation model developed at LISER Luxembourg to predict distributional, behavioural and revenue effects of changes in the Luxembourg tax-benefit system. The structure of the model is inspired by the Swedish micro simulation model SWEtaxben (for details of SWEtaxben see Ericson et al. 2009) and it consists of four components: Program for Start/Input Data, Modelling for calculation of disposable income or Budget Set Program, Program for Behavioral model, and Control/main program. Below we describe these four components in details. 


\subsection{Program for Start/Input Data}

This is the program which generates Start/Input Data and creates the basic building blocks for each of the different types of module runs. All information of individual and household characteristics as well as income components that are independent of hours of work are provided by this program. The Start Data is then used for estimating the necessary parameter in behavioral models as well as calculating disposable income using different modules. An important characteristic of this program is that it classifies all individuals into different status especially for those who are outside of the labor market. Below we describe eight different status based on age or occupation:

Individual status:

1. Child

2. Old age pension

3. Student

4. Disability/sick

5. Parental leave

6. Unemployed

7. Other

8. Employed

The way it classifies all individuals into different groups ensure that each individual belongs to one of this groups. This classification relates to full time status during the base year and is primarily based on the main income source. For example an individual is classified as pensioner if he receives the largest part of income from old age pension; similarly he is classified as a disabled if he receives the bulk part of income from old age pension. For student if he receives study loan. And so on. Of course some of the individuals (for example children) are very trivial. Their age related criteria do not follow the rule of income source. Therefore all individuals less than 18 are classified as a child and all individuals above 70 as an old age pensioner. It is worth to mention that all individuals involves in the simulations are not involved in the behavioral/stochastic models. For example individuals classified as children, students or on 
parental leave as well as older children living with their parents are only included indirectly. All their available information of income is used in the calculation of household disposable income but this information is calculated in the Start Data and does not change in the simulation. Since LuxTaxBen is a static model people do not age and therefore a child is a child before and after a reform.

\subsection{Modelling for calculation of disposable income or Budget set Program}

This part is primarily a tool for calculation of household disposable income evaluated at actual working hours. Suppose a couple determine their hours of work and consumption by maximizing household utility $\mathrm{U}\left(\mathrm{C}, \mathrm{h}_{\mathrm{m}}, \mathrm{h}_{\mathrm{f}}\right)$ subject to the budget constraint ${ }^{1}$ :

$$
\mathrm{C}=\mathrm{C}_{\mathrm{m}}+\mathrm{C}_{\mathrm{f}}+B \text { and } \mathrm{C}_{\mathrm{j}}=\mathrm{w}_{\mathrm{j}} * \mathrm{~h}_{\mathrm{j}}+\mathrm{y}_{\mathrm{j}}+\mathrm{v}_{\mathrm{j}}-\mathrm{t}\left(\mathrm{X}_{\mathrm{j}}\right) ; \mathrm{j}=\mathrm{m} \text { for male and } \mathrm{f} \text { for female. }
$$

Where $\mathrm{C}$ is the household disposable income; $\mathrm{w}^{*} \mathrm{~h}$ is the labor income (where $\mathrm{w}$ is the grosswage per hour and $\mathrm{h}$ is hours of market work per year). $\mathrm{y}$ is non labor taxable income. $\mathrm{v}$ is non labor non- taxable income. Income taxes are determined by the tax function $\mathrm{t}(\mathrm{X})$ and the argument of taxable income $\mathrm{X}=\mathrm{w}^{*} \mathrm{~h}+\mathrm{y}-\mathrm{D}$ and $\mathrm{D}$ is deductions/allowances. The amount means-tested subsidies are given by B, (social assistance, housing allowance, cost of childcare, etc). The income components included in $\mathrm{v}$ (such as the national child allowance) are not dependent on $\mathrm{h}$ and therefore calculated in the Program for Start Data and kept constant throughout the simulation. The income components included in y can be either dependent or independent on h. Capital gains for instance are independent of $h$ whereas unemployment benefits and other transfers that are income dependent are calculated in Budget set Program. The simple principle (which however is not always followed) is that an income component that is not dependent on h is calculated in Program for Start Data and kept constant throughout simulation, whereas all other incomes are calculated in the Budget set program ${ }^{2}$. Taking information of individual and household characteristics as well as income components that are independent of hours of work, several tax-transfers modules in Budget set Program determine all relevant sources of income and taxes needed to calculate individual and household disposable income. All

\footnotetext{
${ }^{11}$ For single household is of course a trivial simplification.

${ }^{2}$ The reason for this principle is that the Budget set Program is called repeatedly for every individual and to speed up the evaluations only the minimum amount of calculation have been included.
} 
tax-transfers modules in Budget set Program are divided into two part: individual part and household part.

\subsubsection{The individual part}

Tax-transfer modules associated to individuals’ specific income are constructed in the individual part and some examples of them are given below:

Disability: There are several disability benefits available in Luxembourg. For example disability allowance for adults, disability allowance for children. The disability ${ }^{3}$ allowance for adults' is known as 'revenu pour personnes gravement handicapées' or Severely Disabled Persons Income. To be eligible to this income a persons must be 18 years or more, at least $30 \%$ disabled, unable to work because of physical or mental incapacity and his disability occurred before the age of 65 . The monthly disability allowance for an adults’ is $€ 1,118.54$. Disability allowance for children is known as a supplementary allowance for disabled children. This allowance is paid to cover the costs related to the child's disability. To be eligible to this allowances, a child must be at least $50 \%$ mentally or physically disabled, less or equal to 18 years or more if the child is in full-time school.

Long-term care cash benefit: Since 1998, long-term care (LTC), either at home or in an institution, is a branch of compulsory social security and is managed at the central level in Luxembourg. It includes all costs of caregiving required for physical or cognitive inability. To be eligible to this benefit the person must be in a situation where he needs assistance of another person for carrying out his daily life activities. The benefit is obtainable at list six months and more than 3.5 hours/week.

Unemployment benefit: In order to qualify for unemployment benefits, the applicant must meet the following conditions:

- must be resident in Luxembourg;

- involuntarily jobless (exempt from the incident of dismissal for gross misconduct) ;

- must be between 16 and 64 years and not entitled for retirement or disability pension;

- ready to accept job;

- register with ADEM (an employment agency);

\footnotetext{
${ }^{3}$ Person who unable to perform his job in the ordinary or the protected environment
} 
- must be in job for at least 26 weeks during last year of enrolling with ADEM.

The unemployment benefit is determined at a rate of $80 \%$ ( $85 \%$ if there are dependent children) of average income in the last 3 months. The benefit cannot exceed 2.5 times the minimum social wage for the first 6 months, 2.0 times the minimum social wage for the next 6 months, and 1.5 time the minimum social wage thereafter. The benefits are payable for a maximum of one year although this can be extended by 6 to 12 months for unemployed persons over the age of 50, and by 182 days in some other circumstances. Unemployment benefits are increased each year in line with the cost of living index and are subject to social security contributions and taxes.

\subsubsection{The household part}

In this phase all transfer system that affect household income are simulated. For example social assistance, housing allowance, and cost of childcare are simulated in this phase. The output is a dataset consisting of households, and recalculated variable (recalculated according to the simulation). The description of some important transfers associated to household' specific income are given below:

The guaranteed minimum income (RMG): The main objective of guaranteed minimum income (RMG) scheme in Luxembourg is to reduce social exclusion, ensure sufficient means for a decent standard of living and set up a measure of professional and social integration ${ }^{4}$. The RMG can be either an integration allowance or a supplementary allowance. A person can be entitled either one of them or both depending on the household situation. These benefits are conditional to age and the resident history of the applicant. To apply for integration benefit a person has to be between 25 and 60 years; be the resident in Luxembourg at least 5 years within the previous 20 years; be involuntarily jobless (exempt from the incident of dismissal for gross misconduct); and be ready to accept job and training; The supplementary allowance is the difference between the family's gross income and maximum amount of the RMG. The calculation of RMG provided by the government depends on household gross income ${ }^{5}$, the rent of the occupied household, the cost of living allowance, and the structure of the household; one adult, or more, children living in the

\footnotetext{
${ }^{4}$ The law issued in 1999 after some modification of the law issued in 1986.

${ }^{5}$ All non means-tested benefits such as family allowances, maternity benefits, long-term care benefits are subtracted from household gross income.
} 
household etc. It is fixed at $€ 1,118.54$ /month for first adult (base amount). For the second adult, the base amount is increased by 50\% (€ 559.27 /month) and for each subsequent adult, the base amount is increased by $€ 320.00$ /month. Additionally, each child is entitled to receive $€$ 101.74/month. RMG is mean tested benefit subject to household gross income

Cost of childcare: Cost of childcare or the "Chèque-service accueil” (CSA ) is an in-kind benefit that gives each child aged 13 years or less at least three free hours of care per week regardless of their parents' income. From the fourth hour of care on, the childcare price varies depending on the income of the parents, the rank of the child in the family and the number of dependent children in the family. The CSA is based on household income, number and age of children and some other household characteristics. For most parents of pre-school children, this policy implied substantially reduced childcare fees; as a consequence, the cost of market work has decreased and improved economic conditions for many families. Ultimately, these childcare measures aim to promote equality of opportunities for children. The idea is the following: by making childcare more accessible and less expensive, these policies help mothers to reconcile work-family life and, through this reconciliation, the equality of opportunities for children is guaranteed.

\subsection{Program for Behavioral model}

To analyze the behavioral responses induced by different tax-transfers reform scenarios, this module offers prediction of labor supply $\operatorname{model}^{6}$. For the prediction of labor supply we use translog specification (equation 1) of the direct utility function proposed by van Soest (1995).

$$
\begin{aligned}
& \mathrm{U}\left(\mathrm{C}, \mathrm{T}-\mathrm{h}_{\mathrm{j}}\right)=\alpha_{1} \log (\mathrm{C})+\alpha_{11}(\log \mathrm{C})^{2}+\alpha_{2}\left(\log \left(\mathrm{T}-\mathrm{h}_{\mathrm{m}}\right)\right)+\alpha_{22}\left(\log \left(\mathrm{T}-\mathrm{h}_{\mathrm{m}}\right)\right)^{2} \\
& +\alpha_{3}\left(\log \left(\mathrm{T}-\mathrm{h}_{\mathrm{f}}\right)\right)+\alpha_{33}\left(\log \left(\mathrm{T}-\mathrm{h}_{\mathrm{f}}\right)\right)^{2}+\alpha_{12} \log (\mathrm{C}) *\left(\log \left(\mathrm{T}-\mathrm{h}_{\mathrm{m}}\right)\right) \\
& +\alpha_{13} \log (\mathrm{C}) *\left(\log \left(\mathrm{T}-\mathrm{h}_{\mathrm{f}}\right)\right)+\alpha_{23}\left(\log \left(\mathrm{T}-\mathrm{h}_{\mathrm{m}}\right)\right) *\left(\log \left(\mathrm{T}-\mathrm{h}_{\mathrm{f}}\right)\right)- \\
& \alpha_{4} \mathrm{P}_{\mathrm{SA}}-b_{f c m} \mathrm{D}_{\mathrm{m}}-b_{f c f} \mathrm{D}_{\mathrm{f}}
\end{aligned}
$$

\footnotetext{
${ }^{6}$ In order to analyze the behavioral responses of choice of disability, old age pension, unemployment etc induced by different tax reform scenarios, the Program for Behavioral model offers prediction of these variables by estimating discrete choice model. However, in the current version, only the labor supply models are included. Future extensions include a module for outsider (unemployment, disability, sickness) as well as a module for pensioner.
} 
In the estimation seven different classes or intervals 0, 1-500, 501-1000, 1001-1500, 1501-2000, 2001-2500, and above 2500 of working hours per year have been used. Thus the choice set for a couple household contains $98(7 * 7 * 2)$ combinations of income $\mathrm{C}$, hours $\mathrm{h}$, and welfare participation.

$\left(\mathrm{T}-\mathrm{h}_{\mathrm{j}}\right)$ is leisure and $\mathrm{T}$ is an upper limit (4 000 hours/year). $\mathrm{P}_{\mathrm{SA}}$ is one if the household is a receiver of social assistance else zero. $\mathrm{D}_{\mathrm{j}}$ is dummy for fixed cost equal to one if working hours is above zero. We assume that the utility function is increasing in income and leisure and decreasing in welfare participation. The disutility from participation in social assistance is assumed to reflect the non-monetary costs, such as fixed costs or "stigma", and is included to account for nonparticipation among eligible families.

In order to implement the model, we also have to specify the nature of heterogeneity in household preferences and the stochastic disturbances. For the household model heterogeneity in preferences for leisure is introduced as,

for male leisure

$$
\alpha_{2}=\sum_{k=1}^{\mathrm{K}} \alpha_{2, k} z_{k}+\phi_{m}
$$

for female leisure $\quad \alpha_{3}=\sum_{k=1}^{\mathrm{K}} \alpha_{3, k} z_{k}+\phi_{f}$

for welfare particiaption $\quad \alpha_{4}=\sum_{j=1}^{\mathrm{J}} \alpha_{4, j} Z_{j}+\phi_{P_{S A}}$

The z-vector includes measurable individual and household characteristics and the $\phi$ 's represents unobserved variables that affect preferences for leisure and welfare participation. As usual it is assumed that an important source for population heterogeneity in terms of preferences for leisure is unobserved. In order to account for this, we formulate a finite mixture model, which allows for unobserved heterogeneity in a very flexible way without imposing a parametric structure. To make the model estimable, additional random disturbances are added to the utilities of all choice opportunities. 
Equation 1 is estimated using information from the "Panel Socio-Economique Liewen zu Lëtzebuerg (PSELL3) ${ }^{7}$. This data is the Luxembourgish share of the European Union-Statistics on Income and Living Conditions (EU-SILC). It includes information based on a sample of individuals taken from the Luxembourg Population of year $\mathrm{t}$ and the collected income information refers to the year t-1 (for example earning form 2009 would be included for the PSELL3/2010). In order to determine the observed heterogeneity of preference for leisure and welfare participation, the model includes age, regional dummy, numbers of children, nationality, and education. Individual with minimum income 12 Euro/hour as well as maximum income 400 Euro/hour are included in the sample. We drop some individual who works more than 4000 hours/year and who is below 18 and over 65 years. We choose couple households where both spouses are in the workforce (status=7 or 8). Household with more than two couples are excluded. Finally a total of 1009 couple households are selected for estimation. Table 2 present the actual and predicted hours of work for

Table 2 presents the percentages of actual and predicted working hours for male and female in couple with 98 combinations using PSEL 2010 (income year 2009).

\begin{tabular}{|c|c|c|c|c|c|c|c|c|}
\hline & & 0 Hour & $\begin{array}{c}250 \\
\text { Hours }\end{array}$ & $\begin{array}{c}750 \\
\text { Hours }\end{array}$ & $\begin{array}{l}1250 \\
\text { Hour }\end{array}$ & $\begin{array}{c}1750 \\
\text { Hours }\end{array}$ & $\begin{array}{l}2250 \\
\text { Hours }\end{array}$ & $\begin{array}{c}2750 \\
\text { and } \\
\text { More } \\
\text { Hours }\end{array}$ \\
\hline \multirow[t]{2}{*}{ Male } & Predicted & 1.68 & 0.10 & 0.59 & 2.08 & 2.48 & 75.02 & 18.04 \\
\hline & Actual & 2.18 & 0.20 & 0.50 & 1.98 & 2.28 & 75.02 & 17.84 \\
\hline \multirow[t]{2}{*}{ Female } & Predicted & 40.14 & 2.68 & 5.35 & 13.38 & 18.83 & 14.97 & 4.66 \\
\hline & Actual & 39.25 & 3.96 & 4.96 & 18.73 & 10.51 & 19.92 & 2.68 \\
\hline
\end{tabular}

\footnotetext{
${ }^{7}$ Estimated parameter of couple, single father, and single mother labour supply models with administrative (IGSS) data are presented in the appendix. The labour supply estimates from PSELL survey data are not presented in the paper but available on request.
} 
Table 3 presents the percentages of actual and predicted working hours for male and female in couple with 18 combinations using PSEL 2010 (income year 2009).

\begin{tabular}{|c|c|c|c|c|}
\hline & & 0 Hour & 750 Hours & $\begin{array}{c}2250 \text { Hours and } \\
\text { more }\end{array}$ \\
\hline \multirow[t]{2}{*}{ Male } & Predicted & 2.78 & 2.68 & 94.55 \\
\hline & Actual & 2.18 & 2.68 & 95.14 \\
\hline \multirow[t]{2}{*}{ Female } & Predicted & 40.63 & 27.65 & 31.71 \\
\hline & Actual & 39.25 & 27.65 & 33.10 \\
\hline
\end{tabular}

male and female in couple. This model was estimated with 98 combinations of working hours, income and welfare participation using PSEL 2010 (income year 2009). The predicted hours are very similar to actual hours for male. However predicted hours for female are somewhat deviated from actual hours particularly working 1250 and more hours’ per year. This could be explain by the fact that our combinations approaches are rather broad which cannot capture well the part time work. Therefore we reduce number of choices of hours from 7 to 3 and estimate the model with $(3 * 3 * 2) 18$ hours, income and welfare participation combinations. Table 3 presents the percentages of actual and predicted working hours for male and female in couple estimated with 18 combinations. The result shows that predicted hours are very close to actual hours.

Table 4 presents the percentages of actual and predicted working hours for male and female in couple with 98 combinations using administrative (IGSS) data 2009.

\begin{tabular}{|c|c|c|c|c|c|c|c|c|}
\hline & & 0 Hour & $\begin{array}{l}250 \\
\text { Hours }\end{array}$ & $\begin{array}{l}750 \\
\text { Hours }\end{array}$ & $\begin{array}{l}1250 \\
\text { Hour }\end{array}$ & $\begin{array}{l}1750 \\
\text { Hours }\end{array}$ & $\begin{array}{l}2250 \\
\text { Hours }\end{array}$ & $\begin{array}{l}2750 \\
\text { and } \\
\text { More } \\
\text { Hours }\end{array}$ \\
\hline \multirow[t]{2}{*}{ Male } & Predicted & 8.73 & 3.06 & 4.70 & 2.80 & 13.15 & 65.22 & 2.34 \\
\hline & Actual & 9.32 & 3.96 & 2.94 & 3.39 & 12.31 & 65.87 & 2.22 \\
\hline \multirow[t]{2}{*}{ Female } & Predicted & 44.79 & 4.81 & 7.75 & 12.39 & 15.90 & 11.93 & 2.43 \\
\hline & Actual & 44.82 & 6.70 & 5.85 & 14.07 & 9.42 & 18.52 & 0.62 \\
\hline
\end{tabular}


Table 5 presents the percentages of actual and predicted working hours for male and female in couple with 18 combinations using administrative (IGSS) data 2009.

\begin{tabular}{|c|c|c|c|c|}
\hline & & 0 Hour & $\begin{array}{c}750 \\
\text { Hours }\end{array}$ & $\begin{array}{l}2250 \\
\text { Hours }\end{array}$ \\
\hline \multirow[t]{2}{*}{ Male } & Predicted & 9.29 & 10.16 & 80.55 \\
\hline & Actual & 9.32 & 10.28 & 80.4 \\
\hline \multirow[t]{2}{*}{ Female } & Predicted & 44.63 & 26.36 & 29.01 \\
\hline & Actual & 44.82 & 26.62 & 28.56 \\
\hline
\end{tabular}

Further, to see from another dimension, we estimate labour supply model for male and female in couple using administrative data available in the data warehouse of General Inspector of Social Security (IGSS) in Luxembourg. Table 4 and 5 present the goodness of fit of labour supply model estimated with 18 and 98 combinations respectively. The data are well fit for both male and female with 18 combinations but as before rather distinct for female with 98 combinations.

So far we have checked the predictive power of labour supply model estimated for couple household. Now we will show how this model perform for single mother and single father. Table 6 presents the percentages of actual and predicted working hours for single father and single mother with $6(3 * 2)$ combinations of working hours, income and welfare participation using administrative (IGSS) data 2009. The findings show that the model fit well.

Table 6 presents the percentages of actual and predicted working hours for single father and single mother with 6 combinations using administrative (IGSS) data 2009.

\begin{tabular}{|lc|rrr|}
\hline & & & 750 & 2250 \\
Single Father & Predicted & 7.77 & 13.40 & 78.84 \\
& Actual & 8.27 & 13.49 & 78.25 \\
\hline \multicolumn{4}{|c}{} \\
\hline Single Mother & Predicted & 20.37 & 24.74 & 54.89 \\
& Actual & 20.71 & 25.11 & 54.17 \\
\hline
\end{tabular}




\subsection{Control/Main Program}

This is the main program which first executes Budget Set program before the reform with existing tax-transfers rules. Of course these rules are implemented in Budget Set program described above. The rules before can either be hypothetical rules or existing rules. The main program then executes Budget Set program after the reform with the new rules. Note that if the simulation is a comparison over time, for instance 2010 and 2014, than changes in prices and income has to be considered. This is considered by different price and income base amounts but earnings have also been indexed and of course also other income sources can be indexed. In order to execute Control Program it is useful to understand all the steps associated with LuxTaxBen (see Figure 1).

Below we describe steps involves with LuxTaxBen. Indeed, these steps will be the same both for the simulation before and after a reform, the only difference is changes in tax-transfer rules.

\section{Figure 1. Structure of LuxTaxBen}

Input1=All income (independent/dependent of working hours) and many other individual and household variables.

Ouput1=Various combination of disposable income and hours of work

Output2=Estimated labor supply model

Output3=Optimum disposable income and hours' work

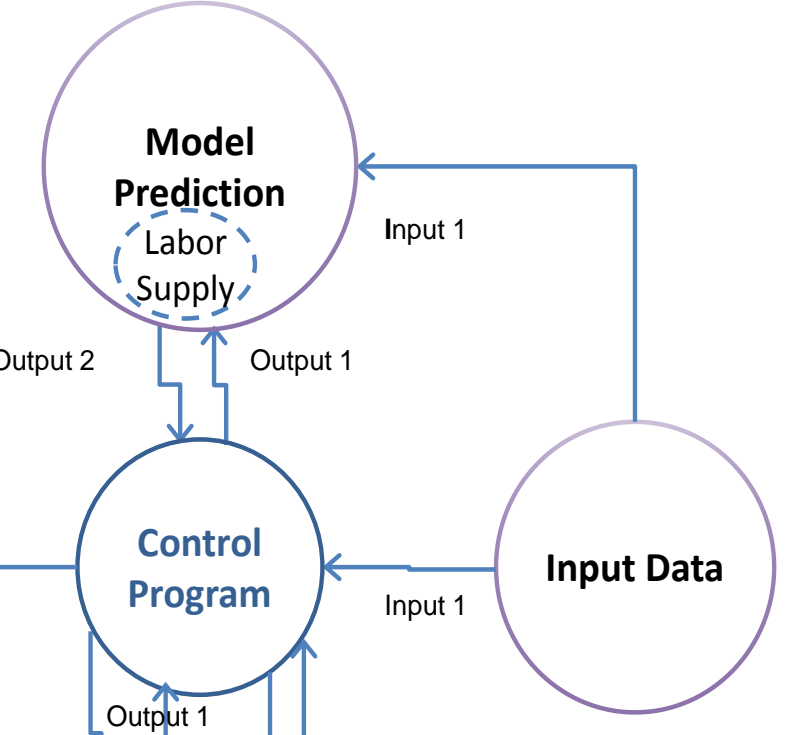

Final output=Optimum disposable income+ optimum hours work + many other individual, household and income variables 
In first step, the control program execute Budget Set program repeatedly and provide output1 (various combinations of disposable income and hours of work) for each individual in the risk population ${ }^{8}$ using input1 (all income and other individual and household characteristics). Thus, for each single household 14 calls (7 working classes with 2 social assistance status) requires to calculate 14 disposable income and for couples this requires 98 calls $(7 * 7 * 2)$ for 98 disposable income to construct his choice set ${ }^{9}$. Note that for the couples at least one of the spouses should belong to the population at risk.

In next step, labor supply model is estimated using input 1 and output 1 to predict working hours, disposable income as well as welfare participation. This step utilize discrete choice model and provide output2 (estimated labor supply model equation 1 described in section 2.3).

Finally, the control program execute Budget Set program again and provide output3 (disposable income) as well as final output (output $3+$ other necessary information required for analysis) using input1 and output2. At this stage the disposable income is calculated at predicted individual-status and at predicted working hours. Thus, this is the predicted disposable income for the individuals/households that are the results of the tax-transfer rules. By changing these rules and repeating the calculation of disposable income before and after a reform can be compared. Of course the results dependent on the econometric models ${ }^{10}$.

\section{Facilities of LuxTaxBen}

One objective of LuxTaxBen is to give the users the opportunity to analyze the effects of planned changes (new rules) in the tax-benefit system. This model can be used by individual researchers as well as governmental and non-governmental offices. As we already mentioned that the LuxTaxBen are developed to model the specific accepted rules in the Luxembourg tax and

\footnotetext{
${ }^{8}$ All individual working or voluntarily non-working are typically known as risk population in traditional labor supply studies. Thus the individual-status 7 and 8 defined in section 2.1 are treated as risk population in LuxTaxBen.

${ }^{9}$ Similarly, for each single household with 3 working classes and with 2 social assistance status requires 6 calls $(3 * 2)$ to calculate 6 disposable income. For couples this requires 18 calls $(3 * 3 * 2)$ for 18 disposable income to construct his choice set

${ }^{10}$ For a detailed see for example Ericson et al (2009).
} 
transfer system. It consists of a number of modules such as module for child benefit, housing allowance, social assistance, fees for child care. It is constructed in an integrated way so all the modules can be used together. This means that it is possible to analyze the interaction between the different transfer systems. The model programs are developed in the SAS-language. One disguising characteristic of this model is flexibility. Meaning that the model is flexible enough to create a new version of it by updating the database and new rules. For additional updates it includes updates of rules according to changes in the tax or transfer systems. The information is adjusted with respect to individual variable values as well as with respect to structural changes of demographic type. The individual variable values in the database are so called "uprated". A number of economic variables are "uprated" by known or expected changes in an index (CPI) correlated with the variable. However characteristics of an individual (for example age, nationality, residence) are not “uprated”.

\section{Robustness}

As it is well known that EUROMOD is a unique source and a recognized standard tool to simulate the effect of tax-transfers reform for the population of each EU countries including Luxembourg. The model enable us to simulate all individual and household income components (including disposable income) using available information from the European Union Statistics on Income and Living Conditions (EU-SILC). Therefore, to control robustness of performance of LuxTaxBen, it will be appropriate to compare the static output between EUROMOD and LuxTaxBen. It is worth to mention that the two model are different by construction although the objective are almost identical. For example EUROMOD makes use of individual unit and LuxTaxBen makes use of household unit to simulate both individual and household level of income. 
Table 3. Comparing income components generated by EUROMOD, EUSILC and LuxTaxBen using of couple household for 2010 (income year 2009) in Luxembourg.

\begin{tabular}{|c|c|c|c|c|}
\hline & Income components & EUROMOD & EUSILC & LuXTaxBen \\
\hline ( a ) & Labor Income & 77457.62 & 77309.36 & 77521.23 \\
\hline ( b ) & Investment income & 1254.37 & 1254.37 & 1254.37 \\
\hline (c) & Income from child below 16 & 7.43 & 7.43 & 7.43 \\
\hline (d) & Pension from private pension plans & 7.22 & 7.22 & 7.22 \\
\hline ( e ) & Property income & 1261.06 & 1261.06 & 1261.06 \\
\hline$(f)$ & Intra house hold transfer received & 91.36 & 91.36 & 91.36 \\
\hline (g) & Maintenance Payments & 430.50 & 430.50 & 430.50 \\
\hline ( h ) & Original income & 79648.56 & 79500.30 & 79712.17 \\
\hline ( 1 ) & Social assistance (RMG) & 653.74 & 228.81 & 752.04 \\
\hline ( j ) & Expensive life allowance & 366.66 & 46.38 & 316.68 \\
\hline$(k)$ & Housing allowance & 326.37 & 326.37 & 311.66 \\
\hline ( 1 ) & Scholarship for Tertiary education & 127.86 & 10.07 & 10.07 \\
\hline$(\mathrm{m})$ & Means-tested benefits & 1474.63 & 611.63 & 1390.46 \\
\hline$(n)$ & Child benefit & 3462.21 & 3474.94 & 3098.94 \\
\hline ( o ) & New school year allowance & 186.41 & 183.12 & 161.58 \\
\hline$(p)$ & Tax bonus for children & 1076.64 & 1035.32 & 1042.64 \\
\hline
\end{tabular}

Continue.. 


\begin{tabular}{|c|c|c|c|c|}
\hline (q) & Accident permanent benefit & 100.63 & 100.44 & 100.44 \\
\hline$(r)$ & Benefit - Care & 12.45 & 12.45 & 12.45 \\
\hline (s) & Benefit - Dependence & 137.61 & 48.97 & 48.97 \\
\hline$(t)$ & Primary and post-primary school subsidies & 3.77 & 0.00 & 0.00 \\
\hline ( $u)$ & Communal subsidies for scholarity & 1.61 & 0.00 & 0.00 \\
\hline ( v) & Education allowances & 225.21 & 225.21 & 225.21 \\
\hline$(w)$ & Benefit - Heavy handicapped Person & 37.84 & 18.22 & 18.22 \\
\hline$(x)$ & Parental leave allowances & 269.26 & 269.26 & 269.26 \\
\hline ( $y)$ & Antenatal, birth, postnatal ben & 55.45 & 55.45 & 55.45 \\
\hline ( $z$ ) & Maternity Allowance (lump-sum) & 25.21 & 24.60 & 24.60 \\
\hline ( aa ) & Maternity payments & 316.12 & 448.22 & 448.22 \\
\hline$(a b)$ & $\begin{array}{l}\text { Other benefits from the solidarity national } \\
\text { fund (FNS) }\end{array}$ & 98.84 & 37.45 & 37.45 \\
\hline$(\mathrm{ac})$ & Unemployment benefit & 776.09 & 1805.80 & 1805.80 \\
\hline$(\mathrm{ad})$ & Sickness benefit & 128.77 & 128.77 & 128.77 \\
\hline ( ae ) & Benefit, if fired & 60.12 & 49.00 & 49.00 \\
\hline ( af ) & Non means-tested benefits & 6974.24 & 7917.19 & 7526.97 \\
\hline ( ag ) & Benefit - Early retirement pension & 1184.71 & 1170.86 & 1170.86 \\
\hline$(\mathrm{ah})$ & Pension - Disability (Invalidity) & 1466.54 & 1463.27 & 1463.27 \\
\hline ( ai ) & Pension for past education of children & 82.58 & 75.14 & 75.14 \\
\hline
\end{tabular}

Continue.. 


\begin{tabular}{|c|c|c|c|c|}
\hline ( aj ) & $\begin{array}{l}\text { Old age pension-Additional from Employer } \\
\text { (2nd pilier) }\end{array}$ & 66.82 & 66.82 & 66.82 \\
\hline ( ak) & Old age pension-For private sector & 3735.22 & 3458.12 & 3458.12 \\
\hline ( al) & $\begin{array}{l}\text { Old age pension-For public sector (régime } \\
\text { général) }\end{array}$ & 2113.52 & 2111.37 & 2111.37 \\
\hline$(\mathrm{am})$ & Old age pension-End of year allowance & 57.50 & 50.58 & 50.58 \\
\hline ( an ) & $\begin{array}{l}\text { Survivors Pension-Private sector (reversion } \\
\text { pension) }\end{array}$ & 415.71 & 68.08 & 68.08 \\
\hline ( ao ) & $\begin{array}{l}\text { Survivors Pension- Public sector } \\
\text { (reversion pension) }\end{array}$ & 6.91 & 6.91 & 6.91 \\
\hline ( ap ) & Pension & 9129.51 & 8471.15 & 8471.15 \\
\hline ( aq ) & Total benefit & 17578.38 & 16999.98 & 17388.58 \\
\hline ( ar) & Tax & 10772.56 & & 10413.49 \\
\hline ( as) & Social security & 10303.71 & & 10401.52 \\
\hline ( at ) & Tax and social security & 21076.27 & 20707.05 & 20815.01 \\
\hline$(\mathrm{au})$ & Taxable income & 88395.03 & na & 89060.40 \\
\hline ( av) & Disposable income & 76150.67 & 75793.23 & 76285.75 \\
\hline
\end{tabular}

Note: $(h)=(a)+(b)+(c)+(d)+(e)+(f)+(g)$

$(m)=(1)+(j)+(k)+(I)$

$($ af $)=(n)+(o)+(p)+(q)+(r)+(s)+(t)+(u)+(v)+(w)+(x)+(y)+(z)+($ aa $)+(a b)+(a c)+(a d)+($ ae $)$

( ap $)=($ ag $)+($ ah $)+($ ai $)+($ aj $)+($ ak $)+($ al $)+($ am $)+($ an $)+($ ao $)$

$(\mathrm{aq})=(\mathrm{m})+(\mathrm{af})+(\mathrm{ap})$

Tax=employment tax +self-employment tax.

Social security= Social security from employment + Social security from self-employment

( av $)=($ h $)+($ aq $)-($ ar $)-($ as $)$

Labor Income=Employment income + Self-employment income. 
For comparison purpose we assume that the reference model is EUROMOD and keep identical name and definition of all income components of LuxTaxBen as similar as in EUROMOD. We choose EUSILC year $2010^{11}$ (income year 2009) and simulate 2282 couple household with or without children as well as with additional single member in the household. We drop some spouses who is below 18 and over 65 years. Income from additional member are considered as non-labor income. In order to make model simpler we drop complex household such as household with two or more couple from the sample. Below we give a short description of the comparison of output between EUROMOD, and LuxTaxBen.

Since input data of both model are originated from EUSILC. Therefore it will give more confidence of robustness of the model if we compare the output of both model with original information EUSILC. The second line of table 3 presents the name of income components and third and fifth lines compare the simulated/non-simulated value of all income components of EUROMOD and LuxTaxBen respectively. The fourth line presents the actual data EUSILC that have been used as input in both model. The row (h) presents on average original income ${ }^{12}$ and the values are: EUROMOD is €79,648.56, EU_SILC is €79,500.30, and LuxTaxBen is €79,712.17. Original income consists of labor income (Employment + self-employment Income), Investment income, Property income, income from child below 16, Intra household transfer received and Maintenance Payments. It is clear that these income components (row a - h) are identical except labor income. This difference, although the difference is not much, can be explained by the different approach of construction of labor income. While in LuxTaxBen the labor income has been constructed by yearly hours of work multiplied by wage ${ }^{13}$ rate and in EUROMOD it is defined by monthly income ${ }^{14}$.

\footnotetext{
${ }^{11}$ Currently available EUROMOD input data for Luxembourg are used.

12 The name (original income) of this income comonents are used in EUROMOD and the level is ils_origy. Similar rule will be followed for all other name of income components.

${ }^{13}$ Wage rate has been constructed by annual labor earning divided by annual hours of work. Both OLS and Heckman selection approach applied to impute missing wage rate for male and female separately and no significant difference between these two approaches. For missing wage rate we use predicted wage.

14 To make comparable monthly income has been multiplied by number of months (12) in the year.
} 
The row (m) presents the means tested benefit which consists of social assistance (RMG), expensive life allowance, housing allowance, and scholarship for tertiary education. One important characteristic of this income group is most of them are simulated by tax-benefit rules. For example, RMG, housing allowance, and expensive life allowance are simulated by the taxbenefit rules in both LuxTaxBen and EUROMOD. The big difference between actual value (in EUSILC) and simulated value (in LxTaxBen and EUROMOD) can be explained by non-take up ratio. In Luxembourg over 65 percent of all households potentially entitled do not claim RMG because of rational motivation; for example expected net utility from claiming, and stigma, play a major role in explaining the level of non-take up (Amétépé F. 2012).

Non-means tested benefits, another income group, contains child benefit, new school year allowance, tax bonus for children, accident permanent benefit, care benefit, dependence benefit, primary and post primary school subsidies, communal subsidies for scolarity, education allowances, benefit for heavy handicapped person, parental leave allowances, antenatal, birth, and postnatal benefit, maternity allowance (lump-sum), maternity payments, other benefits from the solidarity national fund (FNS), unemployment benefit, sickness benefit, and the benefit if fired. Almost all income components in this group are rather similar in EUROMOD and in LuxTaxBen as well as in input data EUSILC. Nevertheless some of them are noticeable different such as unemployment benefit. This benefit, on average, reported in EUROMOD is €776.09/year, in EUSILC is €1805.80/year, and in LuxTaxBen €1805.80/year. This benefit is simulated in EUROMOD but not in LuxTaxBen. In LuxTaxBen it is observed as it in EUSILC. Child benefit, new school year allowance, tax bonus for children are simulated in both EUROMOD and LuxTaxBen. These simulations depend on number and age of children in the household. For example child benefit for 1 child is €185.6*12/year, for 2 children is $€ 440.72 * 12$ /year, for 3 children is $€ 802.74 * 12 /$ year, and for more than 3 children is $€ 802.74 * 12+(361.82 *$ (number of children-3)*12)/year. New school year allowance for 1 child aged 6-11 is €113.15/year, for 2 children is $€ 194.02 * 2 /$ year, and for subsequent children is $€ 274.82 *$ (number of subsequent children)/year. Moderation d'impôt pour enfant was a benefit that applied only to families who paid income tax. This benefit has been replaced by a bonus for children (boni pour enfant) in 2008. This bonus applies to all families with children eligible for family allowances and the bonus is $€ 922.50$ year per child. 
Row (ar) presents the pension income which contains benefit from early retirement, disability/invalidity pension, pension for past education of children, old age pension additional from employer, complement pension for miners and metal workers, old age pension for private sector, old age pension for public sector (régime général), old age complement pension for war captivity, old age pension for end of year allowance, survivors pension for private sector (reversion pension), and survivors pension for public sector (reversion pension). LuxTaxBen produce all of these pension components almost identical to EUROMOD but not exactly identical as it is with EUSILC. Again these differences can be explained by the definition of the pension components.

As we mentioned earlier and as in other micro simulation model, LuxTaxBen has ultimate objective is to generate disposable income. Therefore, in the end of the simulation, the model produce household disposable income which is equal to original income plus total benefit subtracted by the total tax and social security contribution. Where total benefit contains pension, means and non-means tested benefit. Total tax and social security contribution contain employment and self-employment tax and social security contribution respectively. Row (av) presents on average household disposable income €76150.67/year in EOROMOD, $€ 75793.23 /$ year in EUSILC, and $€ 76285.75 /$ year in LuxTaxBen which are very closed each other.

\section{Discussion and conclusion}

Tax micro simulation modelling is used in economic policy analysis to assess the distributional consequences of a tax or benefit change among heterogeneous group of families and to estimate the likely cost to the government of a proposed or hypothetical policy reform. The most common type of model is non-behavioural in the sense that the behaviour is assumed exogenous to the tax and benefit system. These model provides impacts or 'morning after effects' of specified change of tax or benefit and can identify gainers and losers. They are based on a large scale cross sectional data set. The advantage of using such a data set, compared with the analysis of a small rage of typical household, is that it is possible to capture the kind of heterogeneity at the individual and households' level that is found in practice. This leads to a more authentic 
assessment of the overall effects of tax and benefit reform and grossing up factors can usually be used to obtain aggregate expenditure levels. However many tax and transfer policies are designed specially to produce labour supply effect and particularly those policies which try to encourage more labour force participation. Tax revenue and expenditure may be misleading if potential labour supply responses are not taken into consideration. Further without modelling behaviour it is not possible to examine the welfare effects of changes, since attention is otherwise restricted to measure of changes in disposable income. Small changes in labour supply may in fact be associated with large welfare changes. For large reforms that has large effects on economic incentives, the assumption that the households do not adapt to these changes is not so realistic. For this reason it is important to develop a micro simulation model that allows for behavioural changes. To this date there is no behavioural micro simulation model has been developed solely for Luxembourg. Therefore we develop a behavioural micro simulation model LuxTaxBen. Such model has a great potential to be used for evaluating the effects of tax-benefit policy reforms and other changes on poverty, inequality, incentives and the governmental budget. A crucial point and an important characteristic of the model is that it includes behavioral effects. It is flexible enough and consequently every year it is possible to create a new version of it by updating the database and new rules.

An important criteria of a micro simulation model is that it should be able to replicate the actual values. Thus, to check predictive power, we estimate a series of labor supply models using various specifications and different data sources. By comparing predicted vs actual hours we conclude that the models fit well. Further we compare all income components and conclude that as a whole LuxTaxBen produce very close output as it is produced by EUROMOD and EUSILC.

One important critique of classical discrete choice labor supply model (Van Soest 1995 type model) is that the model does not take into account the demand side effect. This is not an equilibrium effect model. Alternatively some other studies (see for example Aaberge et al. 1995, 1999, and 2008) propose an attractive approach that partly solves that problem by considering demand side restriction in the estimation. However the problem with this approach is that the model is data demanding. A problem of this approach on data from PSELL is the small sample 
size. However an interesting future challenge is to estimate a model that allows for a more realistic view on the demand side by using administrative data. 


\section{References}

Aaberge, R., Dagsvik, J.K., \& Strøm, S. (1995). Labor Supply Responses and Welfare Effects of Tax Reforms. Scandinavian Journal of Economics, 97(4), 635-659.

Aaberge, R., Colombino, U., \& Strøm, S. (1999). Labor Supply in Italy: An Empirical Analysis of Joint Household Decisions, with Taxes and Quantity Constraints. Journal of Applied Econometrics,14(4), 403-422.

Aaberge, R., \& Colombino, U. (2008). Designing Optimal Taxes with a Microeconometric Model of Household Labour Supply. CHILD Working Paper no. 06/08.

Aaberge, R., \& Flood, L. (2008). Evaluation of an In-Work Tax Credit Reform in Sweden: Effects on Labor Supply and Welfare Participation of Single Mothers. IZA Discussion Paper No. 3736.

Amedeo Spadaro (2007). "Microsimulation as a tool for the evaluation of public Policies: methods and applications”--Amedeo Spadaro(ed), Bilbao : Fundación BBVA, 2007. 357 p. ; 24 cm; isbn 978-84-96515-17-8

Amétépé F. (2012). “The effectiveness of Luxembourg's minimum guaranteed income.” International social security review, 65(1), pages 99-116.

BERGER Frédéric, ISLAM Nizamul, LIEGEOIS Philippe (2011). "Behavioral micro simulation model and labor supply in Luxembourg”. Brussels Economic Review, 2011, Vol.54, n²4, Winter 2011.

Brewer, M., Browne, J., Emmerson, C., Goodman, A., Muriel, A., Tetlow, G., (2007). "Pensioner poverty over the next decade: what role for tax and benefit reform?”, IFS Commentary No. 103. The Institute for Fiscal Studies. 
Creedy J. and Duncan A. (2002) "Behavioural micro simulation with labour supply responses.” Journal of economic survey. Vol 16, No 1.

Dekkers, G., Belloni, M., (2009). "Micro simulation, pension adequacy and the dynamic model MIDAS: an introduction.” Project AIM - Deliverable 4.10.

Dekkers, G., Buslei, H., Cozzolino, M., Desmet, R., Geyer, J., Hofmann, D., Raitano, M., Steiner, V., Tanda, P., Tedeschi, S., (2010). "What are the consequences of the European AWGprojections on the adequacy of pensions? An application of the dynamic micro simulation model MIDAS for Belgium, Germany and Italy.” Life-Cycle Microsimulation Modelling. Constructing and Using Dynamic Microsimulation Models, 325-357.

Ericson, P, Flood, L.R, Wahlberg, R., 2009, "SWEtaxben: A Swedish Tax/benefit Micro Simulation Model and an Evaluation of a Swedish Tax Reform”, IZA DP No. 4106

EUROMOD-https://www.iser.essex.ac.uk/euromod.

Flood, L (2008). “Chapter 3 SESIM: A Swedish Micro-Simulation Model, in Anders Klevmarken, Björn Lindgren (ed.) Simulating an Ageing Population: A Microsimulation Approach Applied to Sweden.” Contributions to Economic Analysis, Volume 285; Emerald Group Publishing Limited, pp.55 - 83.

Gaëtan de Menten, Gijs Dekkers, Geert Bryon, Philippe Liégeois and Cathal O'Donoghue (2014). “LIAM2: a New Open Source Development Tool for Discrete-Time Dynamic Microsimulation Models “Journal of Artificial Societies and Social Simulation 17 (3) 9.

Klevmarken, N.A., (2010). "Microsimulation for public policy: Experiences from the Swedish model SESIM, Economics and Social Research.” Institute Discussion Paper 242. Cabinet Office, Tokyo, Japan. 
LIEGEOIS Philippe, ISLAM Nizamul (2013). "Dealing with Negative Marginal Utilities in the Discrete Choice Modeling of Labor Supply”. Economics Letters, 2013, vol. 118, n 1, pp. 16-18.

O'Donoghue, C., Lennon, J., Hynes, S., (2009). “The Life-cycle Income Analysis Model (LIAM): a study of a flexible dynamic microsimulation modelling computing framework”. International Journal of Microsimulation 2, 16-31.

Peichl, A., Schneider, H., Siegloch, S., (2010). “Documentation IZAYMOD” The IZA Policy INTERNATIONAL JOURNAL OF MICROSIMULATION (2013) 6(2) 3-55 52.

Sutherland, H., 2007. EUROMOD: the tax-benefit microsimulation model for the European Union, in: Harding, A., Gupta, A. (Eds.), Modelling our future: population ageing, health and aged care. Elsevier, Amsterdam, pp. 483-488.

Van Soest A. (1995). Structural Models of Family Labor Supply: A Discrete Choice Approach. Journal of Human Resources, 30, 63-88. 


\section{Appendix:}

Table A4 presents the estimated parameter of couple household labour supply model with 98 combinations using administrative (IGSS) data 2009.

\begin{tabular}{|c|c|c|}
\hline Variable & Coefficient & SE \\
\hline \multicolumn{3}{|l|}{ Husband's leisure: } \\
\hline Intercept & 30.57 & 0.25 \\
\hline Big City & 0.37 & 0.04 \\
\hline Primary school & -1.12 & 0.05 \\
\hline Secondary school & -0.91 & 0.04 \\
\hline Age $18-30$ & -0.13 & 0.05 \\
\hline Age $31-40$ & -0.27 & 0.04 \\
\hline Age 41-50 & -0.03 & 0.01 \\
\hline Age $51-60$ & 0.00 & 0.00 \\
\hline No. Children & -0.20 & 0.02 \\
\hline No. Child 0-5 & 0.13 & 0.02 \\
\hline \multicolumn{3}{|l|}{ Wife's leisure: } \\
\hline Intercept & 9.51 & 0.12 \\
\hline Big City & 0.29 & 0.03 \\
\hline Primary school & 0.49 & 0.03 \\
\hline Secondary school & 0.19 & 0.02 \\
\hline Age $18-30$ & -1.48 & 0.05 \\
\hline Age $31-40$ & -1.24 & 0.04 \\
\hline Age $41-50$ & -0.70 & 0.03 \\
\hline Age $51-60$ & 0.00 & 0.00 \\
\hline No. Children & 0.41 & 0.01 \\
\hline No. Child 0-5 & 0.25 & 0.02 \\
\hline \multicolumn{3}{|l|}{ Welfare: } \\
\hline Intercept & 7.06 & 0.05 \\
\hline Big city & 0.43 & 0.03 \\
\hline Husband Luxembourgish & 0.66 & 0.03 \\
\hline Wife Luxembourgish & 0.76 & 0.06 \\
\hline Husband with Primary education & -0.24 & 0.04 \\
\hline Wife with Primary education & -0.18 & 0.03 \\
\hline Husband Age 18-30 & -0.92 & 0.04 \\
\hline Husband Age 31-40 & -0.49 & 0.03 \\
\hline Wife Age $18-30$ & 0.02 & 0.01 \\
\hline Wife Age 31-40 & 0.00 & 0.00 \\
\hline No. Children & -0.50 & 0.02 \\
\hline No. Child 0-5 & 0.17 & 0.06 \\
\hline
\end{tabular}

Continue Table A4 ... 
Continue Table A4 ...

\begin{tabular}{|c|c|c|}
\hline \multicolumn{3}{|l|}{ Utility parameters: } \\
\hline b1 & 2.768 & 0.037 \\
\hline a11 & 0.077 & 0.003 \\
\hline a22 & -20.656 & 0.135 \\
\hline a33 & -4.083 & 0.049 \\
\hline a12 & -0.307 & 0.011 \\
\hline a13 & -0.452 & 0.011 \\
\hline a23 & -0.741 & 0.063 \\
\hline \multicolumn{3}{|l|}{ Fixed costs: } \\
\hline Husband & 1.925 & 0.042 \\
\hline Wife & 2.593 & 0.024 \\
\hline \multicolumn{3}{|l|}{ Unobserved Heterogeneity } \\
\hline \multicolumn{3}{|l|}{ Husband's leisure: } \\
\hline & -11.468 & 0.003 \\
\hline & 18.810 & 0.134 \\
\hline & -7.342 & 0.088 \\
\hline \multicolumn{3}{|l|}{ Wife's leisure: } \\
\hline & -2.672 & 0.003 \\
\hline & -1.452 & 0.139 \\
\hline & 4.125 & 0.189 \\
\hline \multicolumn{3}{|l|}{ Welfare: } \\
\hline & 8.272 & 0.003 \\
\hline & -3.914 & 0.043 \\
\hline & -4.358 & 0.038 \\
\hline \multicolumn{3}{|l|}{ Type probabilities: } \\
\hline & 0.65 & \\
\hline & 0.19 & \\
\hline & 0.16 & \\
\hline Log-likelihood value: & 120654.59 & \\
\hline Number of observations & 42346 & \\
\hline
\end{tabular}


Table A5 presents the estimated parameter of couple household labour supply model with 18 combinations using administrative (IGSS) data 2009.

\begin{tabular}{|c|c|c|}
\hline Variable & Coefficient & SE \\
\hline \multicolumn{3}{|l|}{ Husband's leisure: } \\
\hline Intercept & 17.85 & 0.14 \\
\hline Big City & 0.88 & 0.05 \\
\hline Primary school & -0.35 & 0.04 \\
\hline Secondary school & -0.82 & 0.04 \\
\hline Age $18-30$ & -0.14 & 0.08 \\
\hline Age $31-40$ & -0.43 & 0.04 \\
\hline Age $41-50$ & -0.40 & 0.04 \\
\hline Age $51-60$ & 0.00 & 0.01 \\
\hline No. Children & -0.25 & 0.02 \\
\hline No. Child 0-5 & 0.11 & 0.03 \\
\hline \multicolumn{3}{|l|}{ Wife's leisure: } \\
\hline Intercept & 5.71 & 0.05 \\
\hline Big City & 0.23 & 0.03 \\
\hline Primary school & 0.31 & 0.02 \\
\hline Secondary school & 0.15 & 0.02 \\
\hline Age $18-30$ & -1.05 & 0.04 \\
\hline Age $31-40$ & -0.84 & 0.03 \\
\hline Age 41-50 & -0.45 & 0.03 \\
\hline Age $51-60$ & 0.00 & 0.01 \\
\hline No. Children & 0.19 & 0.01 \\
\hline No. Child 0-5 & 0.18 & 0.02 \\
\hline \multicolumn{3}{|l|}{ Welfare: } \\
\hline Intercept & 5.11 & 0.43 \\
\hline Big city & -2.80 & 0.45 \\
\hline Husband Luxembourgish & -20.98 & 0.43 \\
\hline Wife Luxembourgish & 0.91 & 0.34 \\
\hline Husband with Primary education & 0.99 & 0.22 \\
\hline Wife with Primary education & -0.51 & 0.57 \\
\hline Husband Age 18-30 & 11.46 & 0.01 \\
\hline Husband Age 31-40 & -1.66 & 0.28 \\
\hline Wife Age $18-30$ & 1.75 & 0.49 \\
\hline Wife Age 31-40 & 0.00 & 0.01 \\
\hline No. Children & -1.60 & 0.18 \\
\hline No. Child 0-5 & 0.95 & 0.27 \\
\hline
\end{tabular}

Continue Table A5 ... 
Continue Table A5 ... Utility parameters:

b1

2.011

0.045

a11

0.135

0.005

a22

$-21.421$

0.100

a33

$-4.340$

0.023

a12

$-0.043$

0.011

a13

$-0.242$

0.010

a23

$-0.418$

0.047

Fixed costs:

Husband

14.093

0.058

Wife

3.087

0.032

Unobserved Heterogeneity

Husband's leisure:

$-11.468$

0.003

18.810

0.134

$-7.342$

0.088

Wife's leisure:

$-7.210$

0.008

3.743

0.314

3.467

0.343

Welfare:

27.803

0.008

$-54.007$

0.114

26.203

0.248

Type probabilities:

Log-likelihood value:

0.520

0.030

0.450

Number of observations

73838.720

42346.000 
Table A6 (Single Father) presents the estimated parameter of single father labour supply model with 6 combinations using administrative (IGSS) data 2009.

\begin{tabular}{|c|c|c|}
\hline Variable & Coefficient & SE \\
\hline Intercept & 2.64 & 0.44 \\
\hline Big City & 0.99 & 0.23 \\
\hline Primary school & -0.40 & 0.21 \\
\hline Secondary school & -0.49 & 0.18 \\
\hline Age $18-30$ & -3.69 & 1.19 \\
\hline Age 31-40 & -4.57 & 1.16 \\
\hline Age $41-50$ & -4.44 & 1.18 \\
\hline Age 51-60 & -4.08 & 1.19 \\
\hline No. Children & 0.17 & 0.09 \\
\hline No. Child 0-5 & -0.31 & 0.11 \\
\hline \multicolumn{3}{|l|}{ Welfare: } \\
\hline Intercept & -12.13 & 3.33 \\
\hline Big city & 0.97 & 0.56 \\
\hline Luxembourgish & 1.92 & 0.58 \\
\hline Primary education & -0.30 & 0.33 \\
\hline Age $18-30$ & -0.17 & 0.42 \\
\hline Age 31-40 & -0.35 & 0.37 \\
\hline No. Children & -0.27 & 0.11 \\
\hline No. Child 0-5 & 0.06 & 0.22 \\
\hline
\end{tabular}

Continue Table A6 (Single Father) ... 
Continue Table A6 (Single Father) ... Utility parameters:

b1

0.883

0.217

a11

0.103

0.027

a22

1.333

0.201

a12

0.206

0.047

Fixed costs:

$-1.152$

0.296

Unobserved Heterogeneity

Leisure:

2.560

0.025

$-7.192$

1.258

4.633

0.698

Welfare:

16.128

0.025

14.898

3.298

$-31.026$

6.528

Type probabilities:

Log-likelihood value:

0.450

0.520

0.030

Number of observations

1903.92

2202 
Table A6 (Single Mather) presents the estimated parameter of single Mother labour supply model with 6 combinations using administrative (IGSS) data 2009.

\begin{tabular}{|c|c|c|}
\hline Variable & Coefficient & SE \\
\hline Intercept & -0.26 & 0.08 \\
\hline Big City & 0.17 & 0.06 \\
\hline Primary school & 0.48 & 0.05 \\
\hline Secondary school & 0.02 & 0.04 \\
\hline Age $18-30$ & -0.62 & 0.20 \\
\hline Age $31-40$ & -1.12 & 0.17 \\
\hline Age $41-50$ & -0.97 & 0.16 \\
\hline Age 51-60 & -0.48 & 0.17 \\
\hline No. Children & 0.50 & 0.04 \\
\hline No. Child 0-5 & 0.28 & 0.06 \\
\hline \multicolumn{3}{|l|}{ Welfare: } \\
\hline Intercept & 8.87 & 2.86 \\
\hline Big city & -0.30 & 0.20 \\
\hline Luxembourgish & 0.59 & 0.12 \\
\hline Primary education & -1.22 & 0.22 \\
\hline Age $18-30$ & -2.81 & 0.47 \\
\hline Age $31-40$ & -1.15 & 0.26 \\
\hline No. Children & -1.36 & 0.21 \\
\hline No. Child 0-5 & 0.45 & 0.14 \\
\hline
\end{tabular}

Continue Table A6 (Mother)... 
Continue Table A6 (Mother) ...

Utility parameters:

b1

0.283

0.066

a11

0.027

0.008

a22

$-0.233$

0.040

a12

$-0.011$

0.009

Fixed costs:

0.001

0.043

Unobserved Heterogeneity

Leisure:

$-1.363$

0.013

0.054

0.034

1.309

0.139

Welfare:

12.760

0.013

$-3.647$

3.191

$-9.113$

3.088

Type probabilities:

$$
\begin{aligned}
& 0.42 \\
& 0.45 \\
& 0.13
\end{aligned}
$$

Log-likelihood value:

12593.92

Number of observations

9211 